Abstract

\title{
Livestock Production: Climate and Sustainability Impacts ${ }^{\dagger}$
}

\section{Dora Marinova * and Diana Bogueva}

Citation: Marinova, D.; Bogueva, D Livestock Production: Climate and Sustainability Impacts. Proceedings 2021, 73, 14. https://doi.org/10.3390/ IECA2020-07787

Published: 10 November 2020

Publisher's Note: MDPI stays neutral with regard to jurisdictional claims in published maps and institutional affiliations.

Copyright: $(2021$ by the authors. Licensee MDPI, Basel, Switzerland. This article is an open access article distributed under the terms and conditions of the Creative Commons Attribution (CC BY) license (http://creativecommons.org/licenses/by/4.0/).
Curtin University Sustainability Policy Institute, Curtin University, Perth, WA 6845, Australia;

Diana.Bogueva@graduate.curtin.edu.au

* Correspondence: D.Marinova@curtin.edu.au

† Presented at the 1st International Electronic Conference on Animals-Global Sustainability and Animals: Science, Ethics and Policy, 5-20 December 2020; Available online: https://ieca2020.sciforum.net/.

\begin{abstract}
Despite abundant evidence about the large contribution of livestock production to climate change and its serious negative impacts on sustainability, it has only recently started to come under scrutiny. Greenhouse gas emissions, deforestation, biodiversity loss, the inefficient use of natural resources, and the application of antibiotics are some of the aspects associated with the current and increasing trends in the supply of livestock food products. With sustainability being an anthropocentric concept, there seems to be little concern about animal exploitation and limited discussion about the role of livestock in improving human quality of life. The presentation provides an overview of the climate and sustainability impacts of livestock production and argues that an increase in the adoption of plant-based options is a win-win situation for all the species on this planet.
\end{abstract}

Keywords: sustainability; livestock; climate change; biodiversity; anthropocene

Supplementary Materials: The following are available online at www.mdpi.com/2504-3900/73/1/14/s1, video presentation.

Institutional Review Board Statement: The study was approved by the Human Research Ethics Committee at Curtin University.

Informed Consent Statement: Not applicable.

Data Availability Statement: Data is contained within the article. 